\title{
Evaluasi Potensi Fisik Siswa Sebagai Hasil Belajar Pendidikan Jasmani, Olahraga dan Kesehatan (Studi pada SMP Sederajat di Kabupaten Jember)
}

\author{
Ardi Bernis Wiranata ${ }^{a}$, I Made Sry Undi Mahardika ${ }^{b}$ \\ ${ }^{a, b}$ Universitas Negeri Surabaya
}

Corresponding author : ardiwiranata@mhs.unesa.ac.id

\section{ARTICLE INFO}

\section{Article history:}

Received 15 August 2017

Received in revised form 21 Sept 2017

Accepted 10 Oct 2017

\section{Keywords:}

Evaluation of students' physical

potential as a result of learning the

physical education, sport, and health,

Junior high school.

\begin{abstract}
A B S T R A CT
This study was conducted to measure the student's achievement in evaluation learning outcomes of physical education. There are five research questions that will be analyzed: (1) how did the teacher understand the learning objectives?, (2) how did the teacher make the learning objectives as the target of evaluation?, (3) how did the teacher's evaluation has been linked with learning objectives?, (4) how did the objectives which designed by the teacher has been effective to improve the student's physical potential?, (5) how did the learning objectives have been achieved?. This study used descriptive qualitative method. The data were collected by using the model of evaluation CIPP (context, input, process, and product). The reasearcher did the observation in Junior high school of distric Jember and chose all student's of class VIII which consist of 1210 student's. The result of the study revealed that: (1) the teacher did not understand the objectives of learning physical education yet, (2) the teacher did not make the learning objectives as a target of evaluation, (3) the teacher's evaluation did not linked with learning objectives, (4) the learning objectives designed by the teacher did not effective to improve the student's potential physic, (5) the learning objectives did not achieving the student's achievement. Based on the explanation above, it is concluded that vitality condition was $57.38 \%$ (healthy student) and $42.62 \%$ (unhealthy student).
\end{abstract}

dalam mencapai tujuan-tujuan pengajaran Penjasorkes.

Tujuan umum (general instructional objective) pembelajaran Penjasorkes di Sekolah Menengah Pertama yang dituangkan dalam Peraturan Menteri Pendidikan Nasional Republik Indonesia (Permendiknas) Nomor 22 Tahun 2006 tentang Standar Isi untuk Satuan Pendidikan Dasar dan Menengah. Bagian A. Kerangka Dasar Kurikulum, Kelompok Mata Pelajaran Jasmani, Olahraga dan Kesehatan pada SMP/MTs/SMPLB "dimaksudkan untuk meningkatkan potensi fisik serta membudayakan sportivitas dan kesadaran hidup sehat".

Peraturan Menteri Pendidikan Nasional Republik Indonesia (Permendiknas) Nomor 23 Tahun 2006 tanggal 23 Mei 2006 pada bagian B di poin 5 yang berbunyi: Kelompok mata pelajaran Jasmani, Olah Raga, dan Kesehatan bertujuan "membentuk karakter peserta didik agar sehat jasmani dan rohani, dan menumbuhkan rasa sportivitas". Sedangkan pada bagian Standar Kompetensi Kelompok Mata Pelajaran (SK-KMP) adalah sebagai berikut: 1) Menunjukkan kebiasaan hidup bersih, sehat, bugar, aman dan memanfaatkan waktu luang dengan memanfaatkan lingkungan dengan bertanggung jawab, 2) Mencari dan menerapkan berbagai informasi tentang potensi sumber daya lokal untuk menunjang hidup bersih, sehat, bugar, aman dan memanfaatkan waktu luang.

Bila dicermati lebih lanjut, sasaran belajar Penjasorkes dalam Permendiknas Nomor 22 dan 23 Tahun 2006 yang berhubungan dengan aspek kecakapan jasmani meliputi kebugaran jasmani (physical fitness), kelincahan (agility), kecepatan dan reaksi (speed and reaction time), kelentukan (flexibility), ketepatan (accuracy), reaksi (reaction), keseimbangan (balance), koordinasi (coordination), daya ledak (explosive power), antropometri (antrophometric: body build and body composition). Oleh karena itu, penting juga dalam upaya peningkatan potensi fisik siswa, 
guru Penjasorkes melakukan evaluasi penilaian terkait tujuan dan sasaran hasil belajar Penjasorkes, sehingga selaras dengan tujuan evaluasi penilaian hasil pembelajaran yang tercantum dalam Peraturan Pemerintah Nomor 19 Tahun 2005 tentang Standar Nasional Pendidikan.

\section{Metode Penelitian}

Penelitian ini menggunakan pendekatan kuantitatif dengan metode deskriptif dengan tujuan untuk mengetahui hasil belajar Penjasorkes di sekolah sebagai bahan evaluasi. Sementara itu, model evaluasi yang digunakan adalah CIPP (Conteks, Input, Process, dan Product), yang mana penelitian ini dikembangkan oleh Stuefflebeam di Ohio State University. Sebagaimana yang dijelaskan oleh Zhang dkk, 2011 "the CIPP evaluation program belongs in the improvement/accountability category and is one of the most widely applied evaluation models". Desain ini dipilih karena CIPP merupakan model evaluasi yang paling banyak dikenal dan diterapkan para evaluator. Model evaluasi CIPP didalam penelitian ini nantinya bertujuan untuk mencakup seluruh komponen pengelolaan pembelajaran Penjasorkes, sehingga hasil akhir evaluasi dapat menyajikan informasi tentang kelebihan dan kelemahan setiap komponen.

CIPP ini terdiri dari empat komponen, yaitu:

1. Context evaluation

Evaluasi konteks adalah upaya untuk menggambarkan dan merinci lingkungan, kebutuhan yang tidak terpenuhi, populasi dan sampel yang dilayani, dan tujuan program. Dalam penelitian ini, evaluasi konteks diarahkan pada tujuan proses belajar Penjasorkes.

\section{Input evaluation}

Evaluasi masukan ditujukan pada kemampuan awal siswa dan sekolah dalam menyelenggarakan proses belajar mengajar Penjasorkes, yang meliputi Rencana Pelaksanaan Pembelajaran (RPP) yang dibuat oleh guru Penjasorkes, dan sarana prasarana yang disediakan.

3. Process evaluation

Evaluasi proses diarahkan pada seberapa jauh kegiatan yang dilaksanakan di dalam program sudah terlaksana sesuai dengan rencana. Dalam penelitian ini, evaluasi proses berfokus pada implementasi (penerapan) pembelajaran Penjasorkes.

4. Product evaluation

Evaluasi produk diarahkan pada hal-hal yang menunjukkan perubahan yang terjadi pada masukan, serta ketercapaian tujuan. Dalam hal ini adalah hasil tujuan belajar Penjasorkes.

Subyek penelitian berjumlah 1210 peserta didik, dimana peserta didik berasal (systematic random sampling) dari 3 sekolah SMP Sederajat yang berdomisili di Kecamatan Desa dan 3 sekolah SMP Sederajat yang berdomisili di Kecamatan Kota di Kabupaten Jember berdasarkan (purposive) kriteria sekolah favorit (unggulan), sedang, dan rendah (kurang).

Pelaksanaan penelitian evaluasi ini berjalan selama 6 bulan atau (1 semester) dengan prosedur ( \pm 2 bulan) kegiatan pre-test 10 komponen kebugaran jasmani, ( \pm 2 bulan) memberi kesempatan guru untuk melanjutkan proses pembelajaran sesuai dengan RPP, $( \pm 2$ bulan $)$ kegiatan pos-test 10 komponen kebugaran jasmani.

Instrumen penelitian yang digunakan adalah tes kebugaran siswa, dimana butir -butir tes adalah sebagai berikut:

1. Tes Kekuatan: a. Push-up, b. Bent Knee Sit-up

2. Tes Daya Tahan : MFT (Multistage Fitness Test)

3. Tes Komposisi Tubuh

4. Tes Kelincahan: Lari bolak balik 10 meter

5. Tes Keseimbangan: Stork Stand Test

6. Tes Kecepatan: Sprint 50 meter

7. Tes Daya Ledak Otot: a. Standing Board Jump Test, b. Vertical Jump Test.

8. Tes Kelentukan: Fleximeter.

9. Tes Koordinasi: Mata dan Tangan (Lempar tangkap bola).

10. Tes Kecepatan Reaksi: The Nelson Hand Reaction Test (Penggaris). Data hasil tes dikonfirmasikan ke dalam tabel norma (sesuai umur siswa) dan selanjutnya diperoleh kategori atau kriteria.

\section{Hasil dan Pembahasan}

Deskripsi konversi data 1210 siswa kelas VIII di Sekolah SMP Sederajat di Kabupaten Jember ke dalam tabel norma diperoleh hasil sebagai berikut:

\begin{tabular}{|l|l|l|}
\hline No & Kategori & Hasil Akhir \\
\hline 1 & Baik Sekali & - \\
\hline 2 & Baik & 2 \\
\hline 3 & Sedang & 614 \\
\hline 4 & Kurang & 594 \\
\hline 5 & Kurang sekali & - \\
\hline \multicolumn{2}{|r|}{ Jumlah } & 1210 \\
\hline
\end{tabular}

Tabel 1. Kategori Hasil Tes Kebugaran Siswa SMP Sederajat di Kabupaten Jember.

Hasil akhir analisis kondisi fisik pada 1210 siswa kelas VIII di Sekolah SMP Sederajat di Kabupaten Jember menunjukkan bahwa tidak ditemukan adanya siswa yang masuk di dalam kategori baik sekali. Untuk kategori baik hanya ada 2 siswa yang mampu memenuhi kriteria, sementara pada kategori sedang terdapat 614 siswa, serta kategori kurang ada 594 siswa dan tidak ada siswa yang termasuk pada kategori kurang sekali.

Berikut adalah hasil kebugaran siswa yang telah dianalisis berdasarkan kategori pada tabel norma:

\begin{tabular}{|l|l|l|}
\hline No & Kategori & Hasil \\
\hline 1 & Bugar & $(616: 1210) \times 100 \%=50.09 \%$ \\
\hline 2 & Tidak Bugar & $(594: 1210) \times 100 \%=49.91 \%$ \\
\hline
\end{tabular}

Tabel 2. Hasil Kebugaran Siswa SMP Sederajat di Kabupaten Jember.

Secara keseluruhan terdapat $50.09 \%$ (616 siswa dari 1210 siswa) yang memiliki kategori kebugaran memadai, sedangkan sisanya sebesar $49.91 \%$ memiliki kategori kebugaran tidak memadai. Artinya hanya 616 siswa secara jasmani memiliki kemampuan memadai untuk melakukan aktivitas jasmani sehari-hari tanpa mengalami kelelahan, serta masih memiliki kemampuan yang memadai untuk melakukan kegiatankegiatan di luar aktivitas harian tersebut dengan baik.

\section{Pembahasan}

Hasil penelitian yang dideskripsikan berdasarkan komponen evaluasi CIPP adalah sebagai berikut:

\section{Context evaluation}

Dalam penelitian ini, evaluasi konteks diarahkan pada tujuan proses belajar Penjasorkes sebagaimana yang dituangkan dalam Peraturan Pemerintah No. 19 Tahun 2005 dan Permendiknas No. 22 dan 23 Tahun 2006. Sebagai hasil diskusi dan evaluasi yang terjadi di lapangan, bahwa pendidik (guru) memahami tujuan belajar Penjasorkes sebagai kemampuan menguasai keterampilan cabang olahraga dan prestasi olahraga. Akibatnya ketika guru melakukan evaluasi hasil belajar Penjasorkes, lebih banyak melakukan tes keterampilan cabang olahraga prestasi. Seperti salah satu contoh rubrik penilaian guru berbunyi "Bentuk gerakan lengan saat melakukan passing atas dan bawah mendorong bola ke depan atas".

\section{Input evaluation}

Dalam menyelenggarakan evaluasi, masukan ditujukan pada kemampuan awal siswa dan sekolah yang meliputi Rencana Pelaksanaan Pembelajaran (RPP) yang dibuat oleh guru serta sarana prasarana yang ada. Hasil evaluasi di lapangan mengarah pada keadaan sekolah berdasarkan domisili (sekolah di Kecamatan Desa dengan sekolah di Kecamatan Kota) 
maupun kriteria (tingkatan sekolah favorit, sedang, dan kurang). Bukti yang terjadi di lapangan menunjukkan bahwa domisili maupun kriteria sekolah masih ada kesenjangan dalam proses belajar mengajar Penjasorkes.

Selanjutnya mengenai Rencana Pelaksanaan Pembelajaran (RPP), setelah proses pengamatan yang terjadi di lapangan menunjukkan bahwa ada sebagian guru menjadikan kebugaran jasmani sebagai sasaran evaluasi. Berikut adalah salah satu contoh kutipan RPP yang dibuat oleh guru Penjasorkes tentang Standar Kompetensi/ Kompetensi Dasar:

Standar Kompetensi:

8. Mempratikkan latihan kebugaran dalam bentuk latihan sirkuit dan nilainilai yang terkandung didalamnya.

Kompetensi Dasar:

8.1 Mempraktikkan latihan kecepatan dan kelincahan anggota badan bagian atas serta nilai disiplin dan tanggung jawab

8.2 Mempraktikkan latihan kecepatan dan kelincahan anggota badan bagian bawah serta nilai disiplin dan tanggung jawab

Kegiatan Pembelajaran:

1. Melakukan latihan kecepatan dan kelincahan otot lengan, dada dan bahu secara berpasangan atau kelompok (mengoper bola, memantulkan bola ke dinding dengan menghitung jumlah operan/menit atau push-up variasikan dengan tepuk tangan.

2. Melakukan latihan kecepatan dan kelincahan otot paha dan kaki secara berpasangan atau kelompok.

3. Melakukan lomba kecepatan dan kelincahan otot lengan, dada dan bahu, kaki dan paha dengan peraturan yang dimodifikasi untuk menanamkan nilai disiplin dan tanggung jawab.

Indikator:

Aspek Psikomotor

1. Melakukan latihan kecepatan dan kelincahan lengan, bahu dan dada (mengoper bola, memantulkan bola ke dinding dengan menghitung jumlah operan/menit atau push-up variasikan dengan tepuk tangan).

2. Melakukan latihan kecepatan dan kelincahan otot paha dan kaki (melompat bangku senam, arah lurus dan zigzag).

3. Melakukan lomba kecepatan dan kelincahan lengan, bahu dan dada, kaki dan paha dengan peraturan yang dimodifikasi.

Aspek Kognitif

1. Mengetahui bentuk latihan kecepatan dan kelincahan lengan, bahu dan dada (mengoper bola, memantulkan bola ke dinding dengan menghitung jumlah operan/menit atau push-up variasikan dengan tepuk tangan).

2. Melakukan latihan kecepatan dan kelincahan otot paha dan kaki (melompat bangku senam, arah lurus dan zigzag).

Aspek Afektif

1. Disiplin dan tangung jawab.

Alokasi Waktu: 2x2x40 menit.

Apabila dievaluasi lebih lanjut, bahwa proses belajar mengajar Penjasorkes di sekolah hanya 2 kali pertemuan dengan alokasi waktu $2 \times 40$ menit. Sementara jumlah jam pelajaran efektif dalam satu semester ada 34 jam (17 minggu x 2 jam pelajaran), jadi sisa jam pelajaran efektif yang lain lebih banyak digunakan untuk proses belajar mengajar yang mengarah pada permainan (cabang olahraga prestasi) bukan dalam ranah tujuan belajar mengajar Penjasorkes.

Selanjutnya pada rubrik penilaian unjuk kerja kebugaran jasmani, aspek yang dinilai antara lain:

1. Melakukan gerakan tepuk tangan di atas kepala sambil meloncatloncat

2. Melakukan lempar tangkap bola kecil dengan cepat

3. Melakukan naik turun tangga

4. Melakukan shuttle run

5. Melakukan zig-zag

Pada evaluasi aspek rubrik penilaian di atas, guru membuat suatu teknik penilaian yang mengindikasikan tentang ketuntasan dan bukan pada tujuan pengukuran kebugaran jasmani peserta didik. Menurut Jarolemek dan Foster (dalam Suryosubroto, 2009:15) bahwa mengajar mengandung tiga peranan besar, yaitu planning for learning and instruction, fasilitatory of learning and evaluation of learning. Apa yang terjadi dilapangan membuktikan bahwa guru kurang memahami bagaimana cara mengukur kebugaran jasmani peserta didik, mengukur potensi fisik peserta didik menurut klasifikasi umur dan norma. Peserta didik kurang memahami tentang potensi apa yang ada dalam diri mereka sendiri dan kelemahan atau kekurangan masing-masing, serta memungkinkan peserta didik belum mampu mengontrol batasan-batasan aktivitas bagi diri mereka sendiri.

\section{Process evaluation}

Evaluasi proses bertujuan untuk mengamati kegiatan proses belajar mengajar Penjasorkes melalui kesesuaian RPP yang dibuat oleh guru. Dalam pengamatan yang terjadi di lapangan menunjukkan bahwa guru cenderung lebih banyak mengajar dengan mengedepankan keterampilan cabang olahraga prestasi. Pada saat kegiatan belajar mengajar Penjasorkes berlangsung, hal yang sering dilakukan oleh guru adalah memberikan arahan kepada siswa tentang teknik yang benar, pengulangan latihan (passing, lempar, lompat, lari dll). Seperti contoh kutipan RPP Penjasorkes "Melakukan variasi dan kombinasi teknik dasar passing (dada, pantulan dari atas kepala, menggiring, shooting dan lay-up shoot) dengan koordinasi yang baik.

\section{Product evaluation}

Evaluasi produk dalam hal ini adalah hasil Evaluasi Potensi Fisik Siswa Sebagai Hasil Belajar Penjasorkes (Studi pada SMP Sederajat di Kabupaten Jember).

\section{Kesimpulan dan Saran}

Dari hasil penelitian Evaluasi Potensi Fisik Siswa Sebagai Hasil Belajar Penjasorkes (Studi pada SMP Sederajat di Kabupaten Jember), dapat disimpulkan sebagai berikut.

1. Kondisi kebugaran jasmani siswa setelah pembelajaran Penjasorkes di sekolah SMP/ Sederajat di Kabupaten Jember ada peningkatan, tetapi masih dalam rata-rata kategori kurang.

2. Komponen biomotor kekuatan (strength), kelentukan (flexibility), komposisi tubuh (IMT), daya tahan (endurance) ada peningkatan setelah pembelajaran Penjasorkes di sekolah SMP/ Sederajat di Kabupaten Jember.

3. Komponen biomotor kecepatan (speed), daya (power), kelincahan (agility), keseimbangan (balance), koordinasi (coordination), kecepatan reaksi (reaction speed) ada peningkatan setelah pembelajaran Penjasorkes di sekolah SMP/ Sederajat di Kabupaten Jember.

4. Hasil kebugaran jasmani siswa belum menjadi tujuan proses belajar Penjasorkes di sekolah SMP/ Sederajat di Kabupaten Jember.

5. Potensi fisik belum dijadikan komponen evaluasi hasil belajar Penjasorkes oleh guru di sekolah SMP/ Sederajat di Kabupaten Jember.

\section{Saran}

1. Guru Penjasorkes harus lebih memfokuskan kegiatan evaluasinya pada sasaran-sasaran evaluasi yang menjadi tujuan pembelajaran Penjasorkes, khususnya yang berkaitan dalam upaya meningkatkan potensi fisik, menanamkan sportivitas dan kesadaran hidup sehat.

2. Meneladani tujuan-tujuan pengajaran Penjasorkes yang tercantum dalam Peraturan Pemerintah Republik Indonesia Nomor 19 Tahun 2005 tentang Standar Nasional Pendidikan, Permendiknas Republik Indonesia Nomor 22 Tahun 2006 tentang Standar Isi untuk Satuan Pendidikan Dasar dan Menengah, dan Permendiknas Republik Indonesia Nomor 23 tahun Tahun 2006 tentang Standar Kompetensi Lulusan untuk Satuan Pendidikan Dasar dan Menengah maka ada empat tujuan penting pengajaran Penjasorkes yaitu: 1) kecakapan gerak dasar, 2) meningkatkan kebugaran, 3) menanamkan dan membudayakan sportivitas, dan 4) kesehatan. Maka sudah seharusnya tujuan-tujuan penting pengajaran Penjasorkes ini dimasukkan dalam rapor, dengan dilengkapi satu cabang keterampilan olahraga (dasar pertimbangan adalah Undang-Undang Sistem Keolahragaan Nasional khususnya Bab IV pasal 6 yang tersurat:

Setiap warga Negara mempunyai hak yang sama untuk:

a. Melakukan kegiatan olahraga; 
b. Memperoleh pelayanan dalam kegiatan olahraga;

c. Memilih dan mengikuti jenis cabang olahraga yang sesuai dengan bakat dan minatnya;

d. Memperoleh pengarahan, dukungan, bimbingan, pembinaan dan pengembangan dalam keolahragaan; dan

e. Mengembangkan industri olahraga.

Bahasan di atas dapat menjadi masukan kedalam rapor berdasarkan kecakapan-kecakapan hasil belajar Penjasorkes adalah: 1) kecakapan gerak dasar, 2) meningkatkan kebugaran, 3) menanamkan dan membudayakan sportivitas, 4) kesehatan, dan keterampilan cabang olahraga (sesuai dengan minat dan bakat masing-masing peserta didik).

3. Lembaga Pendidikan Tenaga Kependidikan (LPTK) yang menghasilkan Guru-guru Penjasorkes perlu meningkatkan kecakapan mahasiswanya dalam bidang evaluasi, bukan saja berupa pengukuran keterampilanketerampilan olahraga tetapi juga pengukuran lain seperti pengukuranpengukuran Penjas (Physical education measurement), psikometri dan sosiometri.

\section{REFERENSI}

Arikunto, S. (2006). Prosedur Penelitian. Jakarta: PT. Renika Cipta.

Giriwijoyo, H.Y.S. Santosa., Didik Zafar Sidik. (2012). Ilmu Faal Olahraga (Fisiologi Olahraga). Bandung: PT. Remaja Rosdakarya.

Harsuki. (2003). Perkembangan Olahraga Terkini. Jakarta: PT.Raja Grafindo Persada.

Kusnanik, N.W., Nasution, J., dan Hartono, S. (2011). Dasar-Dasar Fisiologi Olahraga. Unesa: University Press.

Lutan, Rusli. (1998). Manusia dan Olahraga. Bandung: ITB Dan FPOK/ IKIP Bandung.

Maksum, Ali. (2012). Metodologi Penelitian dalam Olahraga. Surabaya: Unesa University Press.

Nurhasan. (2011). Menjaga Kebugaran Jasmani. Gresik: Abil Pustaka.

Peraturan Pemerintah Republik Indonesia Nomor 19 Tahun 2005 Tentang Standar Nasional Pendidikan. Jakarta

Peraturan Menteri Pendidikan Nasional Republik Indonesia Nomor 22 Tahun 2006 Tentang Standar Isi Untuk Satuan Pendidikan Dasar Dan Menengah. Jakarta.

Peraturan Menteri Pendidikan Nasional Republik Indonesia Nomor 23 Tahun 2006 Tentang Standar Kompetensi Lulusan Untuk Satuan Pendidikan Dasar Dan Menengah. Jakarta.

Program Pascasarjana. (2012). Pedoman Penulisan Tesis dan Disertasi. Surabaya: Unesa.

Roji dan Eva Yulianti. (2014). Pendidikan Jasmani Olahraga dan Kesehatan. Jakarta: Pusat Kurikulum dan Perbukuan, Balitbang, Kemendikbud.
SriUndy M., I.Made. (2010). Evaluasi Pengajaran. Surabaya: Unesa University Press.

(2009)."Profil Kebugaran Jasmani Anak Usia 07 s/d 13 Tahun sebagai Sasaran Evaluasi Penjasorkes". Surabaya: Jurnal Pendidikan Dasar Vol.10, No.1 Maret 2009 (94-106).

Sudijandoko, Andun. (2008). "Evaluasi Pendidikan Jasmani dalam Pendekatan Portofolio”. Universitas Negeri Surabaya: Jurnal Pelangi Ilmu Vol.2, No.2 Juli-Desember 2008. Diunduh pada tanggal 21 April 2015 dari http://pelangiilmu.jurnal.unesa.ac.id/.

Suharjana. (2012). "Pengukuran Tingkat Kebugaran Jasmani Siswa SD Di Kabupaten Banyumas Jawa Tengah Sebagai Dasar Evaluasi Proses Pembelajaran Pendidikan Jasmani Di Sekolah". Yogyakarta: Indonesian Sport Scientist Association. Jurnal Ilmiah Keolahragaan, No.1,Th.I, Februari 2012, Nomor ISSN: 2252-3375. Diunduh pada tanggal 8 Maret 2017 dari http//www.issa-indonesia.com. 